\title{
Exploring Climate Change Threats to Beach Tourism Destinations: Application of the Hazard-Activity Pairs Methodology to South Africa
}

\author{
JONATHAN FRIEDRICH \\ Institute of Geography, University of Göttingen, Göttingen, and Leibniz Centre for Agricultural Landscape Research \\ (ZALF), Müncheberg, Germany \\ JANNIK STAHL \\ Institute of Geography, University of Göttingen, Göttingen, Germany \\ GIJSBERT HOOGENDOORN \\ Department of Geography, Environmental Management and Energy Studies, University of Johannesburg, Johannesburg, \\ South Africa \\ JENNIFER M. FITCHETT \\ School of Geography, Archaeology and Environmental Studies, University of the Witwatersrand, Johannesburg, South Africa
}

(Manuscript received 22 October 2019, in final form 9 May 2020)

\begin{abstract}
Climate change poses significant threats to the sustainability of tourism economies globally. This is particularly true for beach tourism, which is highly dependent on the mean climate, daily weather, and natural setting of a destination to attract and satisfy tourists. This case study of the South African coastline provides new insights to the applicability of the vulnerability assessment methodology of hazard-activity pairs to the global south and specifically to sub-Saharan Africa. Through this method, tourists' climate perceptions were analyzed and related to potential future impacts of climate change, creating hazard-activity pairs. Tourists' perceptions of climate were captured by means of a questionnaire. Downscaled CMIP5 climate projections (RCP4.5 and RCP8.5) for six weather stations close to major beach tourism destinations were used to estimate changes in precipitation and temperature. This study reveals that future projections of a mean reduction in precipitation and increasing temperature may have positive rather than negative direct effects on South African beach tourism destinations because what tourists perceive as "comfortable" weather conditions are increasing in prevalence. Nevertheless, indirect and induced effects of an already changing climate, defining further hazard-activity pairs, must be considered in vulnerability assessments. This work endorses the applicability of the hazard-activity pair methodology to South Africa and the global south at large.
\end{abstract}

\section{Introduction}

Tourism is one of the largest economic sectors in the world [United Nations World Tourism Organization (UNWTO) 2018], with market strength derived through leisure and recreational travel, including beach and coastal tourism (UNWTO 2018). Climate change alters the suitability of weather for tourism and the aesthetic quality of natural settings, which in turn favors or hinders tourism to varying degrees (Hall 2018; Scott et al.

\footnotetext{
Corresponding author: Gijsbert Hoogendoorn, ghoogendoorn@ uj.ac.za
}

2015). This is of particular concern for outdoor tourism (including beach tourism), as this subsector directly relies on climate and weather (Georgopoulou et al. 2019; Rutty and Scott 2014, 2016; Scott and Lemieux 2010). Despite some locations benefiting economically from climate change impacts through adequate adaption strategies (Tervo-Kankare et al. 2018b), the majority are exposed to various threats, significantly affecting the tourism numbers (Scott et al. 2015). Continued research exploring the sustainability of tourism under climate change is important to ascertain the level of economic threat and future of the tourism sector due to climate change. Additionally, the analysis of potential 
threats related to climate change provides the basis for social-ecological transformation processes in the tourism industry (Calgaro et al. 2014; Scott and Gössling 2015).

South Africa is considered to be the biggest tourism market in sub-Saharan Africa with 10.5 million international arrivals in 2018 (UNWTO 2020) and a total of 44.4 million domestic overnight trips in 2017 (Statistics South Africa 2017). Indeed, tourism is regarded an important tool for future economic development for this country, contributing $7.0 \%$ of the gross domestic product (GDP) in 2019 (Rogerson 2016; World Travel and Tourism Council 2020). Although there are no official statistics in South Africa, beach tourism is an important tourism segment in South Africa. According to Pandy and Rogerson (2018), beach tourism is the biggest market segment of domestic tourism in South Africa.

Against this backdrop, our study explores the impact of climate change-induced temperature and precipitation change through hazard-activity pairs. This follows the methodology of Moreno and Becken (2009), advanced by Kilungu et al. (2019) for the South African beach tourism sector, built on results from a questionnaire survey on climate perceptions of beach tourists that have been outlined previously (see Friedrich et al. 2020) and climate projections based on the Climate Information Platform (CIP 2019).

\section{a. Climate change adaption in the tourism sector}

The ability of a tourism sector or destination to adapt to environmental and climatic changes is a key focal area for tourism planners and governmental institutions on global, regional, and local scales (Moreno and Becken 2009). However, the concept of vulnerability emerged out of the field of hazard-risk studies exploring complex impacts of climate change and aimed at analyzing potential threats to specific areas (e.g., Agard and Schipper 2014; Füssel 2007; O'Brien et al. 2004; Polsky et al. 2007; Santos-Lacueva et al. 2017; Turner 2016). These frameworks have since been used to define the vulnerability of the tourism sector in the context of climate change (e.g., Kaján and Saarinen 2013; Kilungu et al. 2019; Moreno and Becken 2009). In this study, the term "vulnerability" refers to the three-dimensional concept of vulnerability, which the Intergovernmental Panel on Climate Change (IPCC) categorizes as exposure, sensitivity, and adaptive capacity (cf. Agard and Schipper 2014). Vulnerability as such is unique to a specific area under study (Füssel 2007). The exposure of this predefined area is captured by the frequency and severity of possible environmental events, including the affected social and material spheres (Polsky et al. 2007). Sensitivity is understood as the perception and condition of the affected social and material spheres (Polsky et al. 2007). In addition, adaptive capacity relates to the access to financial resources and governance mechanisms (policy as well as stakeholders) in that specific area (Polsky et al. 2007).

Moreno and Becken (2009) unpacked this concept and defined a five-step methodology to assess the vulnerability of coastal tourism destinations to climate change impacts. On the one hand, this framework allows for a comprehensive picture of the destination's vulnerability, including various indicators and multiple threats. On the other hand, the complexity of inputs and required information is time consuming, which leads many scholars alongside policy makers and stakeholders to use certain parts of the framework only. The identification of hazard-activity pairs is a component of the comprehensive methodology that simplify the complex impacts of climate change on touristic destinations and specific touristic action (Moreno and Becken 2009). Here, potential climate hazards are analyzed and explicitly linked to tourism activities focusing on the dimensions of exposure and sensitivity. To achieve this, existing climate data and information on the specific needs and perceptions of tourists are imperative. The primary benefit of the "hazard-activity pairs" approach is the possible integration of many different types of climate change impacts within a single conceptual framework. This is exemplarily applied by Kilungu et al. (2019) in a study on the relation of land-cover changes and touristic activities in the Kilimanjaro National Park.

Globally, considerable research has explored the implications of climate change for the tourism sectors of Europe (Georgopoulou et al. 2019; Gómez-Martín and Martínez-Ibarra 2012; Pintassilgo et al. 2016; Rutty and Scott 2010; Steiger 2010; Steiger et al. 2019) and of small island states (e.g., Kurniawan et al. 2016; Scott and Verkoeyen 2018; Truong and Le 2018). Kilungu et al. (2019) highlight that a significant knowledge gap remains on empirical studies on climate change and tourism in Africa (see also Hall 2018; Hoogendoorn and Fitchett 2018b; Scott and Verkoeyen 2018). This is echoed in a review of the considerations on climate change implications for the tourism industry that are captured in the IPCC Fifth Assessment Report (Scott et al. 2016a).

Research on climate change implications for the African tourism industry has increased over the past decade (e.g., Dube and Nhamo 2018, 2019; Fitchett et al. 2016a; Fitchett and Hoogendoorn 2018; Hambira et al. 2013; Pandy 2017; Pandy and Rogerson 2018; TervoKankare et al. 2018a). Recent research has analyzed tourism stakeholders' perceptions of climate change threats to nature-based tourism in the Okavango Delta (Hambira et al. 2013), Namibia (Tervo-Kankare et al. 2018a), Victoria Falls in Zimbabwe (Dube and Nhamo 2019), and Zambia (Dube and Nhamo 2018) alongside the Hwange 
National Park, Zimbabwe (Mushawemhuka et al. 2018). Implications on Tanzanian tourism attractions such as the Serengeti (Kilungu et al. 2017) and Kilimanjaro (Kilungu et al. 2019) have also been explored. For South Africa, Preston-Whyte and Watson (2005) were the first to research climate change implications for the tourism sector. Hoogendoorn and Fitchett (2020) reflect that the research of Preston-Whyte and Watson (2005) provides a valuable starting point for this sub discipline of tourism studies, which lead to a substantial increase of studies focusing on the explicit impacts of climate change on tourism development in this region. This growing research corpus includes analyses of stakeholders' perspectives on climate change (Pandy 2017; Pandy and Rogerson 2018), coupled stakeholder-tourist perceptions on climate threats (Fitchett et al. 2016a; Hoogendoorn et al. 2016), and later on tourists experiences of weather (Fitchett and Hoogendoorn 2018; Giddy et al. 2017). In addition, Dube and Nhamo (2020), in a recent study of the Kruger National Park, found that climate change and climate variability already influence tourism, highlighting the effects on fauna and flora, touristic activities and infrastructure. This aligns with findings of the National Biodiversity Assessment of South Africa (South African National Biodiversity Institute 2019), which underline that almost $50 \%$ of South African ecosystems are under threat. Additionally, the assessment shows that among others, beaches are at risk, which has implications for recreational activities.

The studies conducted in South Africa have, among others, found that the origin of tourists influences their climate perceptions (Fitchett and Hoogendoorn 2018, 2019; Friedrich et al. 2020; Giddy et al. 2017). This aligns with global studies (see Lam et al. 2018; Rutty and Scott 2015). Therefore, the underlying study uses origin as an additional factor in the application of the hazardactivity pairs methodology in terms of the distinction between international and domestic tourists.

Research on climate change and tourism in the global south remains limited and suffers from issues such as the lack of tourism specific studies, and challenges relating to the accessibility and availability of free climate data and climate model outputs (Hall 2018; Hoogendoorn and Fitchett 2018b; Scott et al. 2015; Scott and Verkoeyen 2018). Nevertheless, Ziervogel et al. (2014) argue that for South Africa, research on climate change itself is comparable with the level of research in Organisation for Economic Co-operation and Development (OECD) countries in general. Nevertheless, freely available digital elevation models to examine the impact of sea level rise on beach tourism destinations are not available in adequate resolution (cf. NASA 2019) to precisely model these impacts; therefore, this study focuses on climate change-induced alternating weather patterns and touristic comfort.

A comprehensive analysis of climate change-induced variability in weather patterns-such as temperature and precipitation but also sunshine, humidity, and changing wind patterns-and its influence on beach tourism in sub-Saharan Africa remains limited (Hoogendoorn and Fitchett 2018b). This is partly because much of the emerging research has focused on nature-based tourism (e.g., Dube and Nhamo 2018, 2019; Tervo-Kankare et al. 2018a) or integrated sea level rise (SLR) impacts (e.g., Fitchett et al. 2016a; Mather and Stretch 2012; Musekiwa et al. 2015; Palmer et al. 2011).

\section{b. Study area}

South African spans the subtropics to midlatitudes, surrounded by two thermally different oceans, resulting in a spatially highly heterogeneous climate (Fitchett 2019) with regional differences between summer rainfall and winter rainfall, and year-round rainfall zones (Roffe et al. 2019). The Great Escarpment divides the country into peripheral coastal areas and an elevated inland plateau. Roughly speaking, an east-west decline in annual precipitation can be detected (Roffe et al. 2019). The coastline with its varying climate zones is directly influenced by the warm Agulhas Current and the cold Benguela Current and indirectly via thermohaline circulation by ENSO (Lennard 2019).

To capture the variety of beach tourism destinations in South Africa, a contiguous transect along the South African coastline was utilized (Table 1). The west coast has been excluded due to its minor contribution to the South African beach tourism sector (Rogerson 2017). The choice of sites includes geographical proximity to weather stations and a variety of different climate zones (Table 1). Reaching from subtropical humid (Cfa) in the northeast, covering Saint Lucia and Durban via hot semiarid regions $(\mathrm{Cfb})$ in the south, including Port Elizabeth and Buffalo Bay among others, to warm summer Mediterranean climate (Csb) around Cape Town (Adesina et al. 2016; Lennard 2019).

\section{Methods}

The hazard-activity pair methodology (Kilungu et al. 2019) was applied to each of the destinations along the coastal transect (Fitchett et al. 2017; Scott et al. 2016b). Future precipitation and temperature trends have been defined as the primary hazard. Due to a lack of freely available data on wind and humidity trends (although the analysis of these weather variables would be valuable for this type of study) in the dataset (CIP 2019) our study is based on, and the considerable diurnal and 
TABLE 1. Climate of the study sites.

\begin{tabular}{|c|c|c|c|c|c|c|}
\hline Destination & $\begin{array}{l}\text { No. } \\
\text { respondents }\end{array}$ & $\begin{array}{l}\text { Mean annual } \\
\text { rainfall (Fitchett } \\
\text { et al. 2017) }\end{array}$ & $\begin{array}{c}\text { Rainfall } \\
\text { seasonality } \\
\text { (Roffe } \\
\text { et al. 2019) }\end{array}$ & $\begin{array}{l}\text { Annual mean } \\
\text { temperature } \\
\text { (Fitchett } \\
\text { et al. 2017) }\end{array}$ & $\begin{array}{l}\text { TCI score (2005-14) } \\
\text { (Fitchett et al. 2017) }^{\mathrm{a}}\end{array}$ & $\begin{array}{c}\text { Köppen-Geiger } \\
\text { climate zone (Peel } \\
\text { et al. 2007) }\end{array}$ \\
\hline Saint Lucia & 100 & $1129 \mathrm{~mm}$ & Summer & $21.6^{\circ} \mathrm{C}$ & 89 (May, Jul)/77.6 (Sep) & Cfa \\
\hline Durban & 105 & $975 \mathrm{~mm}$ & Summer & $20.9^{\circ} \mathrm{C}$ & 91 (May)/77.4 (Nov) & Cfa \\
\hline Port Elizabeth & 51 & $453 \mathrm{~mm}$ & Year-round & $17.4^{\circ} \mathrm{C}$ & 90 (Jan)/67 (Jun) & $\mathrm{Cfb}$ \\
\hline $\begin{array}{l}\text { Cape Saint } \\
\text { Francis and } \\
\text { Jeffreys Bay }\end{array}$ & 101 & $453 \mathrm{~mm}^{\mathrm{b}}$ & Year-round & $17.4^{\circ} \mathrm{C}^{\mathrm{b}}$ & $90(\mathrm{Jan}) / 67$ (Jun) $^{\mathrm{b}}$ & $\mathrm{Cfb}$ \\
\hline $\begin{array}{l}\text { Plettenberg Bay } \\
\text { and } \\
\text { Buffalo Bay }\end{array}$ & 102 & $779 \mathrm{~mm}^{\mathrm{c}}$ & Year-round & $17^{\circ} \mathrm{C}^{\mathrm{c}}$ & $93(\mathrm{Feb}) / 67.5(\mathrm{Jul})^{\mathrm{c}}$ & $\mathrm{Cfb}$ \\
\hline Cape Town & 103 & $853 \mathrm{~mm}$ & Winter rain & $16.9^{\circ} \mathrm{C}$ & 97 (Jan)/56 (Jun) & Csb \\
\hline
\end{tabular}

${ }^{\text {a }}$ The TCI is a quantitative measure to describe the climatic suitability of a tourism destination, ranging from 0 to 100 , where values below 10 define impossible climatic conditions and values above 90 classify ideal climatic conditions. It incorporates data on daytime thermal comfort, average thermal comfort, total monthly rainfall, monthly average sunshine hours, and monthly average wind speed [for more information, see Fitchett et al. (2017)].

${ }^{\mathrm{b}}$ Because of a lack of data, indicators refer to the city of Port Elizabeth.

${ }^{\mathrm{c}}$ Because of a lack of data, indicators refer to the city of Knysna.

seasonal variability in these coastal locations, only precipitation and temperature were selected for this study. The lack of available high-resolution digital elevation models (NASA 2019) and the data challenges to project climate change-induced droughts (James et al. 2018) led the researchers to focus on the aforementioned factors for the creation of hazard-activity pairs. This means that the aim of our study is specifically focused on temperature and precipitation changes under climate change and its influence on beach tourism, based on survey results. Indirect effects such as droughts are not considered in the study. Following the hazard-activity pair methodology, beach tourism has been defined as the (recreational) activity-with particular emphasis on relaxing (often sunbathing) at the beach (such as the beach users surveyed in this study) (Rutty and Scott 2015).

Climate perceptions of 562 tourists were captured through a questionnaire and put in relation to each defined hazard. The fieldwork was conducted during the tourism peak season (Statistics South Africa 2017) over a 4-week period (23 November-19 December 2017) at the beaches of main tourism destinations along the South African coastline (Fig. 1). All adult tourists visiting the particular beach (sitting, walking, or lying on the beach) on the days in question who were willing to participate were selected for the survey. Beside demographic data (such as year of birth, income, education, and country of residence), the questionnaire included quantitative close-ended questions on personal climatic preferences and related behavior, adapted from the work of Denstadli et al. (2011). The questions included personal preferences on different climate and weather-related statements such as the influence on destination or accommodation choice, alongside potential climatic and nonclimatic factors for trip cancellation (among others: floods, cold, persistent rain, political instability, malaria, terrorism, fires, high humidity) and decision-making during the holidays based on the weather (such as restaurants and outdoor activities), which was captured by means of a Likert scale [see Friedrich et al. (2020) for more information]. The sample included 562 beach tourists of which $186(33 \%)$ were domestic and 376 $(67 \%)$ were international travelers.

\section{a. Precipitation and beach tourism}

The hazard-activity pair of rainfall and relaxing at the beach is explored through the questionnaire-derived data on beach tourists' climate perceptions in South Africa and secondary climate data (Gómez-Martín and Martínez-Ibarra 2012).

The questionnaire results reveal whether persistent rain represents a factor that would cause tourists to cancel their trip and/or whether rain leads to an extension of holiday plans. In addition, Gómez-Martín and Martínez-Ibarra (2012) found rain to be a crucial factor for beach tourism. They defined the threshold of rain for beach tourism as $<1 \mathrm{~mm}$ per day in Spain and $<60 \mathrm{~min}$ of rain per day in the Mediterranean Sea region. According to Gómez-Martín and Martínez-Ibarra (2012), the number of rain days is seen to be a threshold for beach tourism: in general, any day with $>5 \mathrm{~mm}$ of rain is defined as heavy rainfall event or persistent rainfall event in South Africa (Dyson 2009). The beach tourists' climate perceptions were analyzed based on the mentioned premises. 


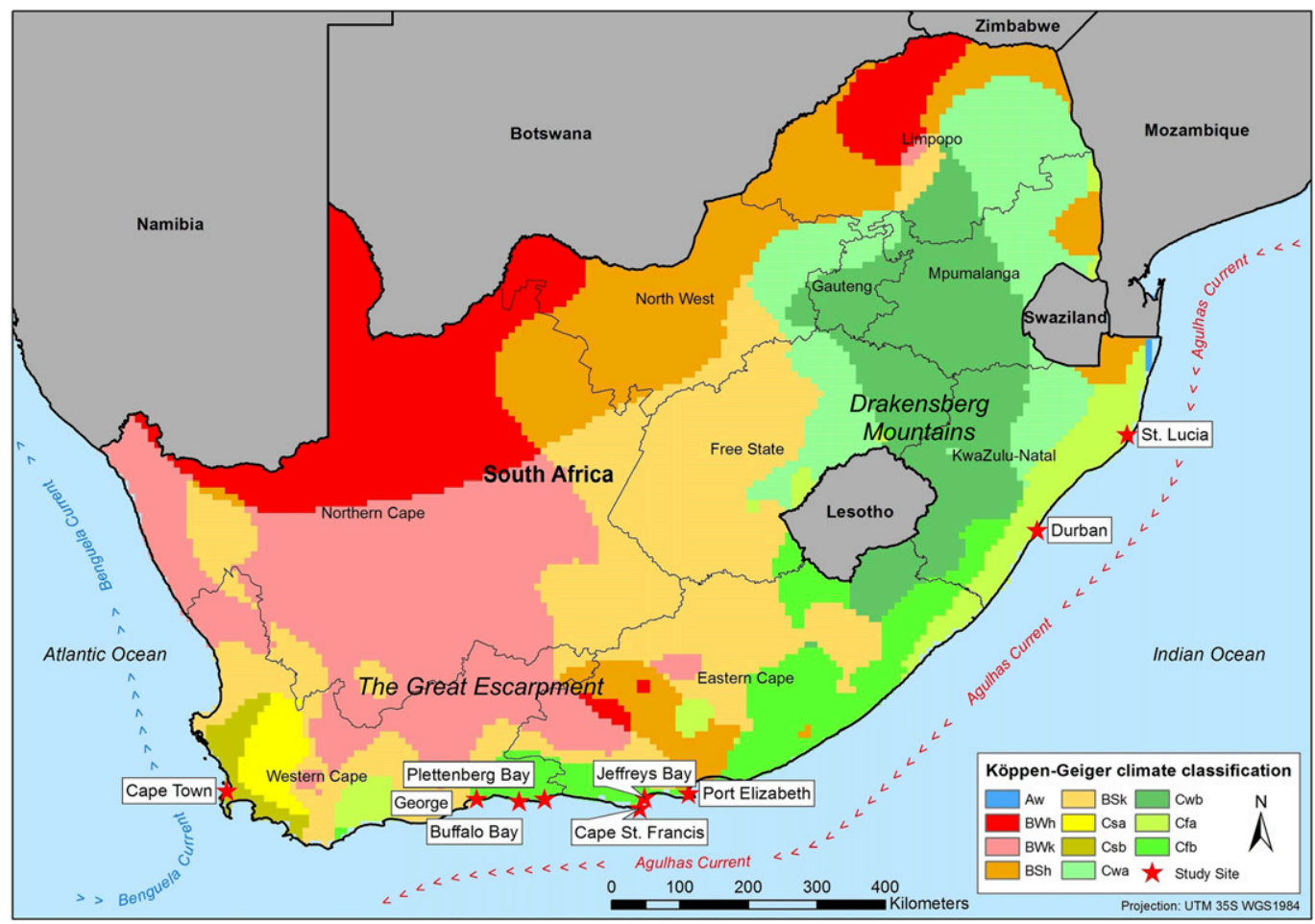

FIG. 1. Study sites, weather stations, South African climate zones, and ocean currents [adapted from Friedrich et al. (2020), based on Peel et al. (2007)].

In accordance to the abovementioned thresholds, the precipitation indices total rain days, rainfall in millimeters, rain days $>5 \mathrm{~mm}$, and rain days $>20 \mathrm{~mm}$ based on CIP (2019; for data source, see below) were used to examine changes.

\section{b. Temperature and beach tourism}

Rutty and Scott (2015), exploring a case study in the Caribbean, argue that high temperatures do not lead to unsuitable conditions for beach tourism. Indeed, Moreno (2010) found temperatures above $22^{\circ} \mathrm{C}$ to be a crucial factor for promoting beach tourism in Spain. These findings were adapted and used to examine the role temperature has on beach tourism under climate change scenarios. Given the similarities in climate with the Caribbean and Spain (Lennard 2019), these studies provide valuable proxy information. Average minimum $\left(T_{\min }\right)$ and maximum ( $\left.T_{\max }\right)$ temperature were used as temperature variables to describe potential future trends (CIP 2019) in combination with questionnaire results. In this respect, days below $22^{\circ} \mathrm{C}$ $T_{\max }$ are regarded as less suitable for beach tourism.

\section{c. Climate change projections}

The CIP (2019) provides data on rainfall amounts, counts of rain days, incidents of rain days $>5$ and $>20 \mathrm{~mm}$, and data on maximum $\left(T_{\max }\right)$ and minimum temperature
$\left(T_{\min }\right)$. The data are available on a monthly level for historical records 1979-2000 (for some stations on a longer scale) and future representative concentration pathway (RCP4.5 and RCP8.5) scenarios among weather stations in (South) Africa. South African weather stations (Table 2) were used for the beach tourism destinations of interest in this study. For each destination, data were retrieved for the nearest weather station to the beach at which questionnaires were completed. Where destinations were located at close proximity to one another (and there was no other weather station), the data of one single weather station were utilized for multiple destinations to extract climatic trends (see Cape Saint Francis and George Airport). Future projections contain both observed and downscaled time series for each station location.

For future scenarios, the downscaled projections are based on CMIP5 models for RCP4.5 and RCP8.5. The RCPs refer to the change in radiative forcing the world is projected to experience in 2100 relative to the preindustrial time (Taylor et al. 2012). These RCPs depend on efforts to reduce emissions, future population growth, new technologies, and societal changes (Taylor et al. 2012; van Vuuren et al. 2011). The following climate model outputs, downscaled through the (CIP 2019), were used in this study: MIROC-ESM, CNRM-CM5, CanESM2, FGOALS-s2, BNUESM, MIROC5, GFDL-ESM2G, MIROC-ESM-CHEM, 
TABLE 2. Mapping of weather stations (CIP 2019) and researched beach tourism destinations for downscaled climate models.

\begin{tabular}{lcl}
\hline \multicolumn{1}{c}{ Weather station } & Station identifier & \multicolumn{1}{c}{ Beach tourism destination } \\
\hline Cape Saint Lucia & SF000068496 & Saint Lucia \\
Durban International Airport & 68588 & Durban \\
Port Elizabeth & 68842 & Port Elizabeth \\
Cape Saint Francis & SF000175820 & Cape Saint Francis/Jeffreys Bay \\
George Airport & 68828 & Plettenberg Bay/Buffalo Bay \\
Cape Town International Airport & 68816 & Cape Town \\
\hline
\end{tabular}

GFDL-ESM2M, MRI-CGCM3, and BCC_CSM1.1. The dataset consists of the monthly means of each climate model.

To analyze the abovementioned climate variables (precipitation and temperature), the months November to February were combined to represent the summer season and encompasses the period of fieldwork. This eliminates possible variabilities between different scenarios. Precipitation variables were totaled annually over these four months while temperature indices have been averaged. The mean, 10th, and 90th percentile for all downscaled climate models for four time periods were used to examine the change over time. Time steps were defined for 2021-30, 2031-40, 2041-50, and 2091-2100 years to meet short-term, midterm, and long-term climate change influence on South African beach tourism sector until the year 2100. This stands in contrast to standard of literature on climatology but meets the time related needs of tourism stakeholders and planners (Lew 2010).

Although climate models in Africa lack precision compared to OECD countries (James et al. 2018), which makes the 2091-2100 time step very inaccurate, we argue that this time step presents data for long-term adaption planning and impact assessments. The reference period refers to the average of the years 1979-2000 because of the lack of more recent data that were available as open source (CIP 2019; Hoogendoorn and Fitchett 2018a; National Centers for Environmental Information 2019).

\section{Results}

\section{a. Climate change projections}

\section{1) FUtURE PRECIPITATION UNDER CLIMATE CHANGE}

The precipitation indices (total rain days, rainfall in millimeters, and rain days $>5$ and $>20 \mathrm{~mm}$ ) are expected to change under scenarios of climate change (RCP4.5 and RCP8.5). The scenarios project differences among the destinations at the South African coastline compared to the reference period of 1979-2000. The questionnaire results that built the basis for this research are reported by Friedrich et al. (2020). These results reveal that rain is crucial for beach tourism in South
Africa, which justifies the application of Gómez-Martín and Martínez-Ibarra's (2012) threshold of rain for beach tourism in this research.

The destinations Durban, Port Elizabeth, and Cape Saint Francis are projected to experience a reduction in precipitation (see Tables 3-6 for explicit values). In terms of total rainfall (rain days, rain days $>5 \mathrm{~mm}$, and rain days $>20 \mathrm{~mm}$ (see Figs. 2 and 3 exemplarily for Durban). The scenarios for the Saint Lucia project that the destination may experience less total precipitation and fewer rain days, but a greater incidence of heavy rainfall events such as rain days $>5$ and $>20 \mathrm{~mm}$. For George, Plettenberg Bay, and Buffalo Bay, the scenarios indicate a decrease of precipitation both in terms of total rainfall and in terms of rain days, while the frequency of occurrence of heavy rainfall events is unlikely to change. Cape Town is the only destination that is expected to experience an increase in total precipitation during the summer months. This is expected to happen as heavy rainfall events, such as rain days $>5$ and $>20 \mathrm{~mm}$, increase as a result of the poleward migration of the westerlies, which is progressively delaying the winter rainfall regime and inducing convective rainfall in summer months (Sousa et al. 2018).

\section{2) Future TEMPERATURE UNDER CLIMATE CHANGE}

In terms of temperature change, similar trends of increases in $T_{\max }$ and $T_{\min }$ are projected for all destinations. Figure 4 displays potential changes exemplarily for the case of the Cape Saint Francis weather station. The RCP8.5 scenarios predict the temperature rise to be intense among all destinations (Table 7). RCP4.5 scenarios project the temperature rise to be of less impact (Table 7). Nevertheless, almost all scenarios at all destinations under both pathways project a temperature increase for both $T_{\max }$ and $T_{\min }$.

\section{b. Hazard-activity pairs}

\section{1) Precipitation}

All destinations (except Cape Town) face a future decline of summer season rain days within the observed 120 days reference period from November to February. 
TABLE 3. Mean absolute changes per decade in rain days $>5 \mathrm{~mm}$ in November-February in relation to the reference period from CIP (2019).

\begin{tabular}{|c|c|c|c|c|c|c|c|c|c|}
\hline \multirow[b]{2}{*}{ Destination } & \multirow[b]{2}{*}{ Reference period } & \multicolumn{4}{|c|}{ RCP8.5 } & \multicolumn{4}{|c|}{$\mathrm{RCP} 4.5$} \\
\hline & & 2025 & 2035 & 2045 & 2095 & 2025 & 2035 & 2045 & 2095 \\
\hline St Lucia & 22 & +2.3 & +1.7 & +2.4 & +1.9 & +1.5 & +2.1 & +1.8 & +2.0 \\
\hline Durban & 21 & -2.7 & -2.6 & -2.3 & -1.9 & -3.3 & -2.5 & -2.6 & -2.7 \\
\hline Port Elizabeth & 8 & -1.1 & -0.4 & -0.6 & -0.5 & -0.6 & -1.0 & -0.5 & -0.5 \\
\hline Cape Saint Francis/Jeffreys Bay & 8 & -0.4 & -0.1 & -0.3 & -0.5 & -0.6 & -0.6 & -0.9 & -0.3 \\
\hline Plettenberg Bay/Buffalo Bay & 12 & +0.8 & +1.0 & +0.8 & +1.0 & +0.8 & +0.6 & +0.5 & +0.9 \\
\hline Cape Town & 3 & +4.8 & +4.8 & +4.2 & +2.5 & +3.8 & +4.0 & +3.8 & +4.3 \\
\hline
\end{tabular}

This means throughout the twenty-first century under IPCC RCP4.5 and RCP8.5, more days become suitable for beach tourism due to the absence of precipitation. On an explicit destination level, this implies that Saint Lucia's present 43 rain days will be reduced between 5 and 12 days throughout this century. While Durban's current 50 days of rain will be lowered by $7-11$ days, Port Elizabeth's 28 rain days will be decreased by 4-5 days. Jeffreys Bay and Cape Saint Francis' current 23 rain days will be cut back by 35 days and Plettenberg Bay and Buffalo Bay's 37 rain days within the mentioned time period will be lessened by 3 to 5 days under the pathway scenarios. Only in Cape Town, the number of unfavorable days (14) for beach tourism will be increased by $1-7$ days.

The majority of the respondents of the questionnaire answered that the occurrence of rain would not lead them to stay longer at the destination; $22 \%$ of the respondents see persistent rain as a factor to cancel their trip. These perceptions did not vary significantly based on respondents' country of origin. Heavy rainfall events of $>5$ and $>20 \mathrm{~mm}$ per day might be perceived as persistent rain by beach tourists if they appear to happen throughout the day. Future projections for Saint Lucia show an increase of up to two rain days $>5$ and $>20 \mathrm{~mm}$. This may potentially lead some tourists to cancel prospective trips to Saint Lucia as these rain events might be experienced more often. In Durban, heavy rainfall events $>5 \mathrm{~mm}$ (reference period: 21 ; decrease: $2-3$ ) and $>20 \mathrm{~mm}$ per day (reference period 7; decrease: 2 ) are expected to decrease in frequency. In Port Elizabeth, these events are already rarely experienced and projected to be lessened under RCP4.5 and RCP8.5. Jeffreys Bay and Cape Saint Francis show very similar findings. This could lead tourists to cancel future trips less often at the four last mentioned destinations as they all may experience less persistent rainfall events of $>5$ and $>20 \mathrm{~mm}$ per day. Heavy rainfall events are expected to remain at the current status around Plettenberg Bay and Buffalo Bay. This possibly indicates that the beach tourism sector of these two destinations does not face threats in terms of heavy rainfall events and connected trip cancellation in the near future. In Cape Town, days with persistent rain $>5$ and $>20 \mathrm{~mm}$ are projected to increase in the future. Therefore, beach tourists here may tend to cancel their prospective trips more often due to these rainfall events.

The projections show a decrease of both the number of rain days and total rainfall for the summer months at all destinations (except Cape Town) in general, and Saint Lucia with regard to heavy rainfall events with $>5$ and $>20 \mathrm{~mm}$ per day. This decline in rain days fosters the climatic suitability for beach tourism in the destinations and may lead to an increase in tourist numbers. It could also result in tourists at all destinations, except Cape Town and Saint Lucia, experiencing a greater enjoyment of their stay, possibly leading to an extension of their vacation at that destination or their future return. Tourists in Saint Lucia may be "forced" to consider the conflicting issues of decreasing total rain days and increasing heavy rainfall events, when deciding

TABLE 4. Mean absolute changes per decade in rain days $>20 \mathrm{~mm}$ in November-February in relation to the reference period from CIP (2019).

\begin{tabular}{|c|c|c|c|c|c|c|c|c|c|}
\hline \multirow[b]{2}{*}{ Destination } & \multirow[b]{2}{*}{ Reference period } & \multicolumn{4}{|c|}{ RCP8.5 } & \multicolumn{4}{|c|}{ RCP4.5 } \\
\hline & & 2025 & 2035 & 2045 & 2095 & 2025 & 2035 & 2045 & 2095 \\
\hline St Lucia & 7 & +0.3 & +0.4 & +0.7 & +0.2 & +0.1 & +0.7 & +0.8 & +0.2 \\
\hline Durban & 7 & -2.4 & -1.8 & -2.0 & -2.4 & -2.5 & -1.8 & -1.9 & -2.4 \\
\hline Port Elizabeth & 2 & -1.0 & -0.6 & -0.8 & -0.6 & -0.7 & -0.7 & -0.6 & -0.6 \\
\hline Cape Saint Francis/Jeffreys Bay & 2 & -0.4 & -0.3 & -0.3 & -0.4 & -0.4 & -0.4 & -0.3 & -0.3 \\
\hline Plettenberg Bay/Buffalo Bay & 2 & -0.7 & -0.4 & -0.4 & -0.2 & -0.6 & -0.3 & -0.3 & -0.4 \\
\hline Cape Town & 0 & +0.6 & +0.9 & +0.6 & +0.4 & +0.4 & +0.7 & +0.4 & +0.6 \\
\hline
\end{tabular}


TABLE 5. Mean absolute changes per decade in total rain days in November-February in relation to the reference period from CIP (2019).

\begin{tabular}{|c|c|c|c|c|c|c|c|c|c|}
\hline \multirow[b]{2}{*}{ Destination } & \multirow[b]{2}{*}{ Reference period } & \multicolumn{4}{|c|}{ RCP8.5 } & \multicolumn{4}{|c|}{$\mathrm{RCP} 4.5$} \\
\hline & & 2025 & 2035 & 2045 & 2095 & 2025 & 2035 & 2045 & 2095 \\
\hline St Lucia & 43 & -5.3 & -4.9 & -5.0 & -5.5 & -10.0 & -12.0 & -10.9 & -9.2 \\
\hline Durban & 50 & -9.6 & -9.4 & -8.9 & -7.1 & -10.0 & -10.8 & -9.4 & -8.8 \\
\hline Port Elizabeth & 28 & -4.7 & -3.9 & -4.2 & -3.8 & -4.3 & -4.4 & -4.2 & -4.6 \\
\hline Cape Saint Francis/Jeffreys Bay & 23 & -3.2 & -2.9 & -3.7 & -5.1 & -3.6 & -4.7 & -4.8 & -4.1 \\
\hline Plettenberg Bay/Buffalo Bay & 37 & -3.5 & -3.5 & -3.4 & -2.9 & -3.6 & -4.3 & -4.4 & -4.1 \\
\hline Cape Town & 14 & +6.7 & +5.9 & +4.8 & +1.5 & +5 & +5 & +4 & +5 \\
\hline
\end{tabular}

whether to cancel or extend their trip. In Cape Town, an increased incidence of rainfall heightens the probability of tourists experiencing rainfall during summer, which may result in more frequent cancellations. However, the questionnaires were conducted during a drought in Cape Town, which could lead tourists to perceive the increase in summer precipitation as for the tourism sector as a whole. This study did not find significantly different responses between domestic and international tourists in relation to their actions under the influence of rain, therefore a differentiation of these two groups are omitted (cf. Friedrich et al. 2020).

\section{2) Temperature}

In general, respondents perceived temperature not to have an influence on their decisions to extend or curtail their trip to a particular South African beach destination. Here the origin of the tourist is a significant discriminator. International tourists viewed high temperatures as significantly more detrimental in their decisions regarding trip extension than domestic tourists. However, among both international and domestic tourists, cold is perceived to be a factor for trip cancellation for some $(13 \%$ of the respondents) beach tourists, while heat is mentioned by very few $(3 \%)$.

Temperature ( $T_{\max }$ and $T_{\min }$ ) projections under RCP4.5 and RCP8.5 reveal similar trends for all of the beach tourism destinations considered in this study (Saint Lucia, Durban, Port Elizabeth, Cape Saint Francis/Jeffreys Bay, Plettenberg Bay/Buffalo Bay, and Cape Town) (see Fig. 4). The increase is steady over the twenty-first century and higher for RCP8.5 than for RCP4.5. The increase rates differ also slightly among the destinations (Fig. 4).

The projected increase in $T_{\max }$ does not appear detrimental to beach tourism along the South African coastline, provided that it does not exceed the absolute limits of human thermal comfort. The respondents of this survey do not see heat as crucial for trip cancellation, meaning that an increase in maximum daily temperature may not lead to increased trip cancellation. Nevertheless, high temperatures were perceived by international tourists to significantly reduce their likelihood to extend their trip, providing a negative outlook under climate change. However, this increase in minimum and maximum daily temperature is likely to lead to less days below an average of $22^{\circ} \mathrm{C}$, and therefore less days with what can be considered minimum threshold temperature conditions for beach tourism. This would also mean fewer tourists cancelling their trip under the threat of cold and may especially effect the beach tourism destinations of the south and southwest coast (Cape Town, Plettenberg Bay/Buffalo Bay, Cape Saint Francis/Jeffreys Bay, and Port Elizabeth), which experienced several days with temperatures below $22^{\circ} \mathrm{C}$ in the reference period of 1979-2000, to benefit from the increase in minimum temperature in terms of tourist numbers.

\section{Discussion}

Through applying the hazard-activity pair methodology, this study reveals key challenges and opportunities for the South African beach tourism sector under climate

TABLE 6. Mean absolute changes per decade in rainfall $(\mathrm{mm})$ in November-February in relation to the reference period from CIP (2019).

\begin{tabular}{|c|c|c|c|c|c|c|c|c|c|}
\hline \multirow[b]{2}{*}{ Destination } & \multirow[b]{2}{*}{ Reference period } & \multicolumn{4}{|c|}{ RCP8.5 } & \multicolumn{4}{|c|}{ RCP4.5 } \\
\hline & & 2025 & 2035 & 2045 & 2095 & 2025 & 2035 & 2045 & 2095 \\
\hline St Lucia & 534 & -36 & -13 & -16 & -46 & -49 & -25 & -41 & -32 \\
\hline Durban & 519 & -153 & -122 & -135 & -143 & -156 & -128 & -133 & -141 \\
\hline Port Elizabeth & 174 & -47 & -32 & -36 & -28 & -38 & -37 & -32 & -34 \\
\hline Cape Saint Francis/Jeffreys Bay & 156 & -28 & -22 & -28 & -34 & -34 & -31 & -35 & -26 \\
\hline Plettenberg Bay/Buffalo Bay & 233 & -32 & -22 & -27 & -16 & -31 & -24 & -27 & -24 \\
\hline Cape Town & 57 & +65 & +71 & +56 & +31 & +49 & +59 & +51 & +58 \\
\hline
\end{tabular}


a)

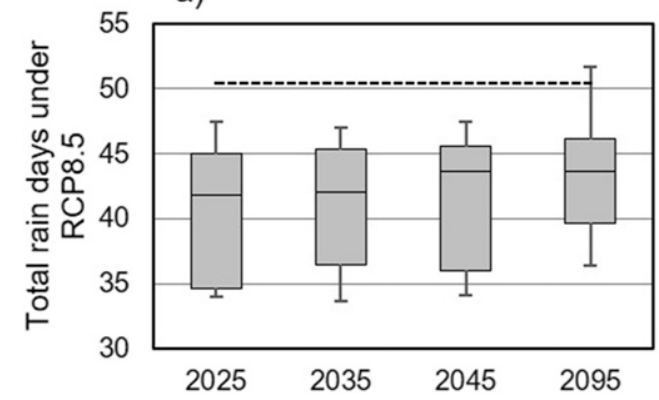

c)

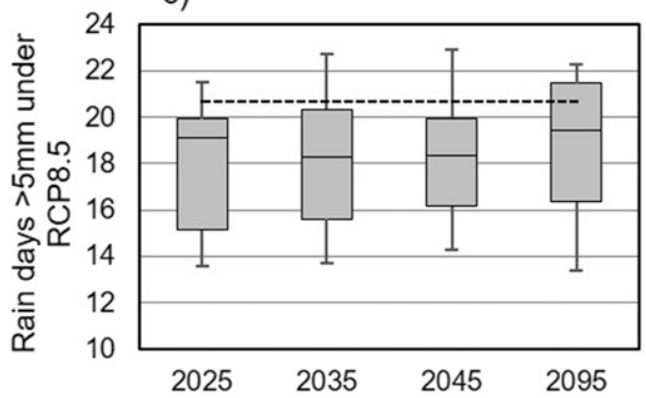

b)

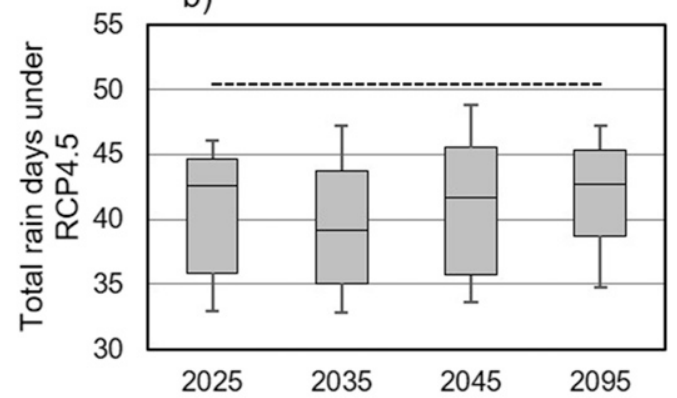

d)

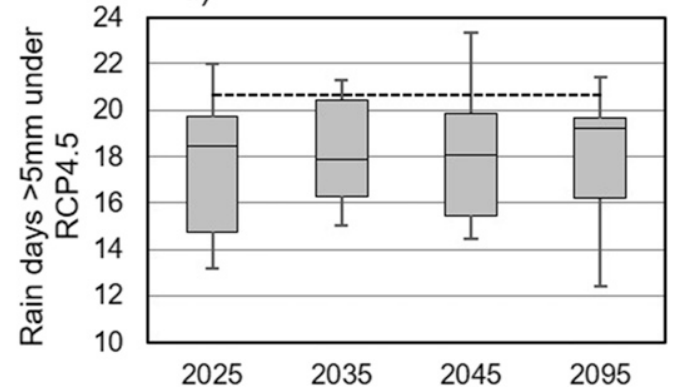

FIG. 2. All values refer to November-February in Durban: (a) total rain days under RCP8.5, (b) total rain days under RCP4.5, (c) rain days $>5 \mathrm{~mm}$ under RCP8.5, and (d) rain days $>5 \mathrm{~mm}$ under RCP4.5. The line refers to the reference period of 1979-2000 [original based on CIP (2019)].

change. The information gathered from this study can contribute to sustainable planning and adaptation within the tourism industry of South Africa to sustain the marked economic contribution.

\section{a. Review of data and methods}

The CIP (2019) provides consistent monthly data for all weather stations spanning 1979-2000. This period does not meet the World Meteorological Organization requirements of a 30-year minimum period for the designation of a climate normal (Agard and Schipper 2014). Because of a lack of consistent monthly climate data on a longer scale for some researched destinations, the CIP data can, however, be argued to be an appropriate source for this application, especially in terms of decadal real time changes that rather meet the time horizons of tourism planning (Lew 2010). The already changing climate (Jury 2019; Kruger and Nxumalo 2017), especially in terms of air temperature, is found to be underestimated through the CIP (2019) data, because periods shorter than 30 years are argued to be insufficient and overestimate historic data (Agard and Schipper 2014). Therefore, climate change and in particular temperature change might be more intense than described in this study. In addition to the CIP (2019), the South African Weather Service (2017) provides climate projections for South Africa, based on nine downscaled CMIP5 models. Both datasets project similar temperature changes from $1^{\circ} \mathrm{C}$ (midterm; RCP4.5) to $3.5^{\circ} \mathrm{C}$ (long term; RCP8.5). In terms of precipitation change, the downscaled models differ. According to the South African governmental Department of Environmental Affairs (2013), it is difficult to adequately project future precipitation change because rainfall in South Africa shows a high interannual variability and the precipitation trends overall appear to be nonsignificant. In addition, observed temperature patterns more precisely fit into climate simulations than rainfall projections (Department of Environmental Affairs 2013). This may explain differences between the data of the CIP (2019) and the South African Weather Service (2017). Furthermore, South African rainfall has significant interannual variability (MacKellar et al. 2014), indirectly influenced by the El Niño phenomena (Lennard 2019) and more locally affected by the southern annular mode, Indian Ocean dipole, and the Madden-Julian oscillation. In addition, several biases are noted in the literature among climate models for the African continent (James et al. 2018).

Numbers, motilities, and socioeconomic background of beach tourists are not documented in South Africa, and therefore extent of bias in this study is uncertain. However, survey results align with the results of previous studies in South Africa (e.g., Fitchett et al. 2016a; Giddy et al. 2017). 
a)

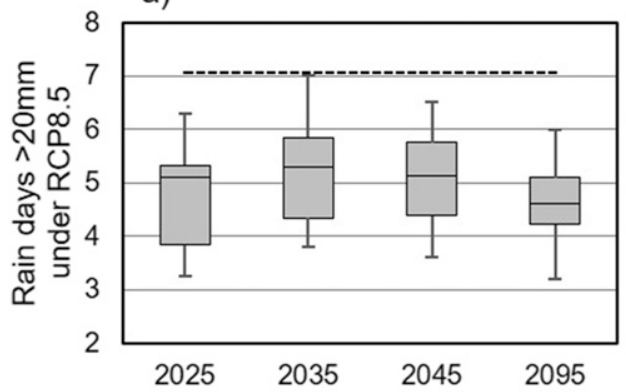

c)

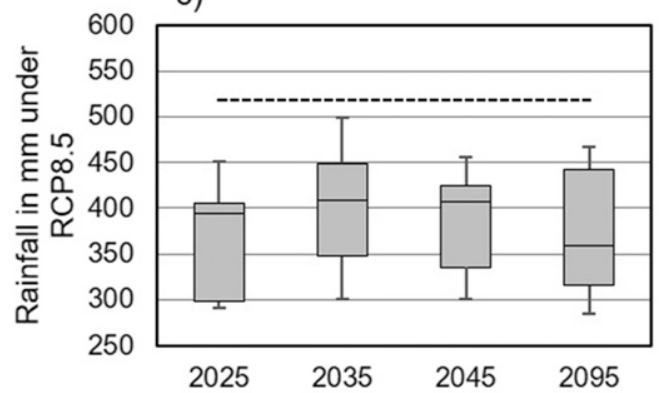

b)

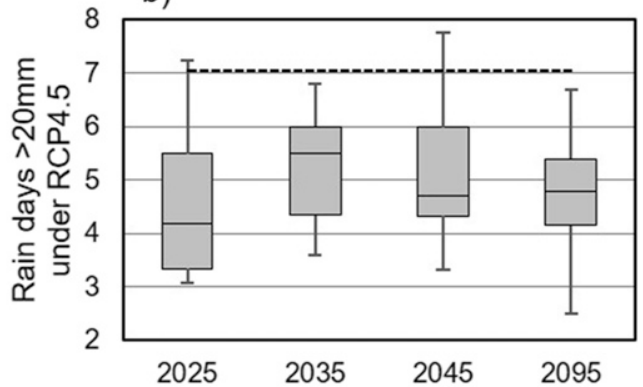

d)

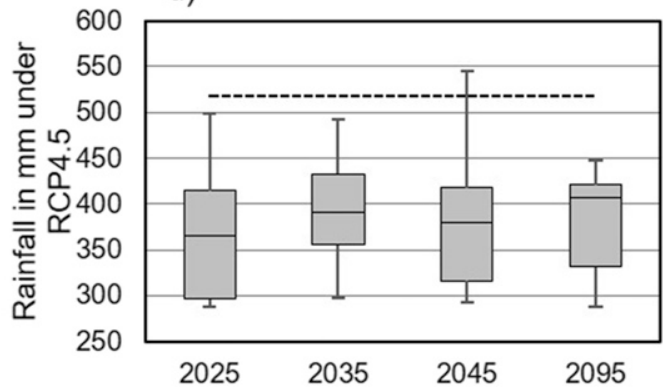

FIG. 3. All values refer to November-February in Durban: (a) rain days $>20 \mathrm{~mm}$ under RCP8.5, (b) rain days $>$ $20 \mathrm{~mm}$ under RCP4.5, (c) total rainfall under RCP8.5, and (d) total rainfall under RCP4.5. The line refers to the reference period of 1979-2000 [original figure based on CIP (2019)].

The hazard-activity pair methodology inherently has limitations. One limitation is due to the abovementioned data paucity common in the African continent (e.g., Kilungu et al. 2019). In addition, the methodology does not address the complex entangled implications of climate change on beach tourism. Wind, humidity, and cloud cover trends, in particular, can be valuable in gaining knowledge on climate change impacts on South Africa's beach tourism sector, despite that there are no projections that include these climate indices. Nevertheless, the hazard-activity pairs methodology allows to analyze specific climatic changes in relation to a specific activity. Focusing on activities rather than tourism segments is potentially useful as activities are primarily linked to touristic behavior. However, it neglects the role climate change can pose to general tourism segments such as eroding destinations or threatening infrastructure. In general, the hazard-activity pair's methodology reduces the complexity and specific data requirements and is arguably helpful where there is a lack of resources to do research, especially in the global south. Furthering the application of this methodology can foster the creation of a holistic picture of climate change impacts on tourism segments in South Africa.

\section{b. Climate change and beach tourism in South Africa}

This study explicitly omitted the effects of SLR although they could potentially be significant, specified in the statement of Jenkins (2018, p. 42) that on a global level, "the major risk factor of coastal destinations is that of SLR and this will be coupled with more extreme weather conditions." This aligns with previous research on SLR and extreme events in South Africa, suggesting negative impacts of climate change on beach tourism (Fitchett et al. 2016a,b; Hoogendoorn et al. 2016; Mather and Stretch 2012; Palmer et al. 2011; Pandy and Rogerson 2018). By explicitly omitting these effects, a key finding of this research is that temperature increases and precipitation change are projected to have a net positive impact on beach tourism destinations in South Africa in terms of current scientific understanding of climatic suitability for tourism (cf. Georgopoulou et al. 2019; Rutty and Scott 2014, 2016; Scott and Lemieux 2010).

Precipitation projections reveal an increase in heavy rainfall events for Saint Lucia under scenarios of climate change (CIP 2019). The rather positive impact on beach tourism through precipitation change is due to losses in total rain days (CIP 2019) in the summer months of November to February. This means that more days become suitable for beach tourism (Georgopoulou et al. 2019; Gómez-Martín and Martínez-Ibarra 2012) in almost all beach tourism destinations (apart from Cape Town's projections). Rain will be the climate factor that most significantly affects beach tourism. The absence of rain is found to be more important than the presence 
a)

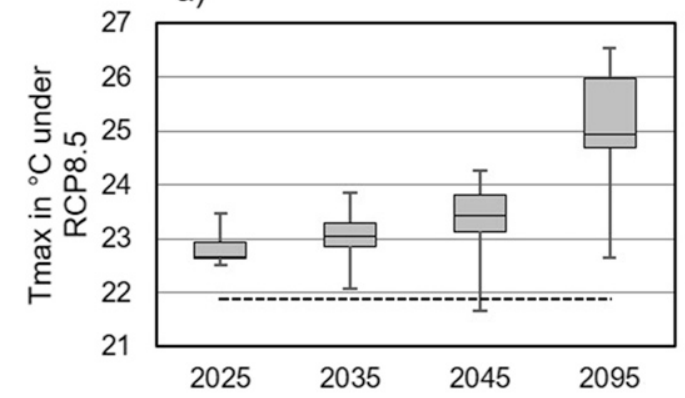

c)

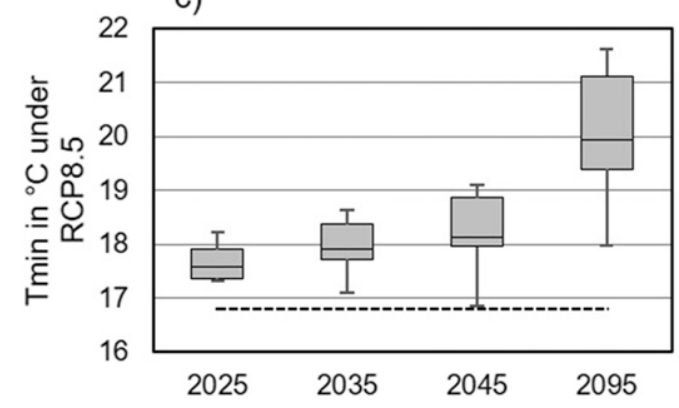

b)

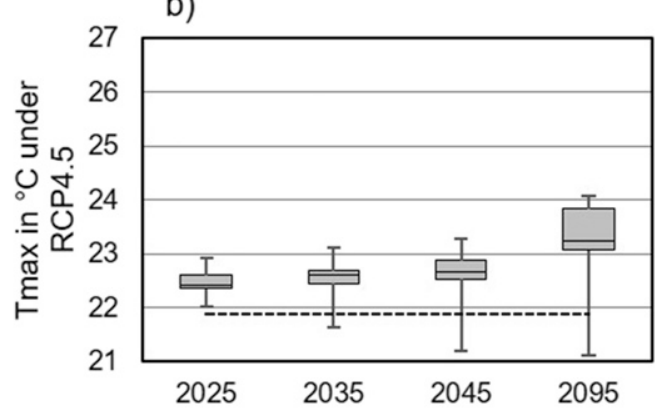

d)

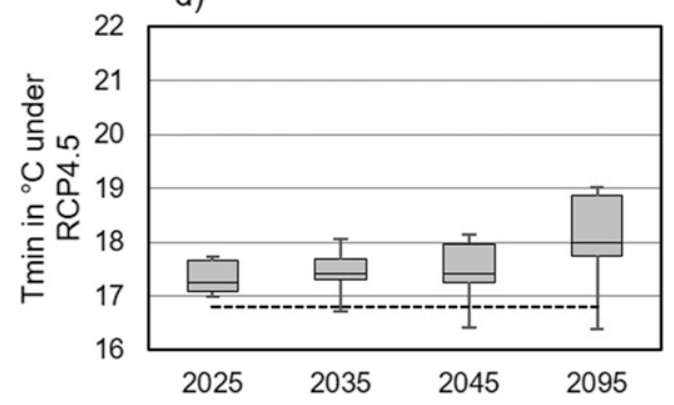

FIG. 4. All values refer to November-February in Cape Saint Francis: (a) maximum temperature trends under RCP8.5, (b) maximum temperature trends under RCP4.5, (c) minimum temperature trends under RCP8.5, and (d) minimum temperature trends under RCP4.5. The line refers to the reference period of 1979-2000 [original figure based on CIP (2019)].

of sunshine (or other weather conditions) for tourists participating in recreational activities at the beach (Georgopoulou et al. 2019; Gössling et al. 2006; Hübner and Gössling 2012). In addition, the coupled and cumulative impact of wind and rain can worsen the perceived comfort.

The extent of changes in precipitation pattern differs in relation to pathway and destination. It is noted that a reduction of rain days can ultimately result in a drought such as Cape Town faced recently (Sousa et al. 2018). It could be argued that a drought would lead to negative effects on tourism numbers as found for the case of Saint Lucia. This is due, among other things, water restrictions and changes in the natural scenery (Fitchett and Hoogendoorn 2018). A spatial assessment of drought severity in Cape Town (Orimoloye et al. 2019) revealed drought related changes in vegetation indices. These findings underline that establishing effective forms of governance and investments to appropriately cope with these implications is of dire need (Ziervogel 2019). In addition, these governance mechanisms are especially needed in view of the water-energy-climate change nexus and the intertwined effects of these phenomena on tourism (Mathetsa et al. 2019).

Furthermore, the temperature is projected to rise under both the RCP4.5 and RCP8.5 scenarios (CIP 2019). This means that the destinations of the south and southwest coast become even more suitable for beach tourism as days with minimum temperature below $22^{\circ} \mathrm{C}$ (Georgopoulou et al. 2019; Moreno 2010) become less frequent. The increased incidence of days with particularly high temperatures do not necessarily affect thermal comfort of beach tourists (Rutty and Scott 2015). Although thermal comfort does go beyond outdoor temperatures, as it is additionally influenced by humidity, wind, and cloud cover, quantified by the physiologically equivalent temperature index (e.g., Perkins and Debbage 2016), as an example. This means that the maximum temperature rise may not have a visibly negative effect on beach tourism in South Africa. Nevertheless, people older than 65 years and children younger than five are of high risk under higher temperatures (cf. Friedrich et al. 2020). This means that the total number of tourists may not change although it could lead to a different age structure of tourists.

Rising temperatures do not have a notably negative impact on beach tourism. This is echoed by the respondents in this study and corroborates the findings of Fitchett et al. (2017) regarding improvements in tourism climate index $(\mathrm{TCI})^{1}$ scores for South African destinations in

\footnotetext{
${ }^{1}$ The tourism climate index is a quantitative measure to describe the climatic suitability of a tourism destination. See Table 1 for more information.
} 
TABLE 7. Range of average temperature changes per decade for November-February among all destinations in relation to the reference period from CIP (2019).

\begin{tabular}{|c|c|c|c|c|c|c|c|c|}
\hline & \multicolumn{4}{|c|}{ RCP4.5 } & \multicolumn{4}{|c|}{ RCP8.5 } \\
\hline & 2025 & 2035 & 2045 & 2095 & 2025 & 2035 & 2045 & 2095 \\
\hline$T_{\min }\left({ }^{\circ} \mathrm{C}\right)$ & $+0.2-0.6$ & $+0.3-0.7$ & $+0.4-0.8$ & $+0.9-1.4$ & $+0.5-1.0$ & $+0.8-1.3$ & $+1.0-1.6$ & $+2.9-3.4$ \\
\hline$T_{\max }\left({ }^{\circ} \mathrm{C}\right)$ & $+0.1-0.8$ & $+0.2-0.8$ & $+0.2-0.8$ & $+0.6-1.4$ & $+0.3-1.2$ & $+0.6-1.4$ & $+0.8-1.6$ & $+2.9-3.3$ \\
\hline
\end{tabular}

recent years. However, the ideal temperature for beach tourism is argued to be situated between $27^{\circ}$ and $32^{\circ} \mathrm{C}$ (Georgopoulou et al. 2019; Moreno 2010; Scott et al. 2008). This means that beach visitors prefer to have a temperature within this range but will tolerate warmer temperatures (Rutty and Scott 2015). In this respect, it could be assumed that the observed range may increase under climate change in the country of origin as this influences the thermal comfort (Potchter et al. 2018; Rutty and Scott 2013, 2015), although it is to differentiate between outdoor temperature and thermal comfort as outlined above. This might mean that the range of projected temperature increases would not directly affect beach tourism negatively as long as it does not exceed the absolute limits of human thermal comfort. In this respect, it needs to be considered that temperature tolerance is higher for beach tourists than for urban or summer mountain tourists (Scott et al. 2008), which means that the projected temperature increase in South Africa may only be positive for the beach tourism sector. Furthermore, it remains unclear whether the global studies on thermal comfort (Georgopoulou et al. 2019; Moreno 2010; Rutty and Scott 2013, 2015) can be applied in terms of South Africa, being suggested by previous research on tourists' climate perceptions (Fitchett and Hoogendoorn 2018; Giddy et al. 2017). Nevertheless, future studies focusing explicitly on thermal comfort and the complex, intertwined relationship of wind, humidity, and temperature for (beach) tourists in South Africa are needed to provide empirical evidence.

In addition, this study focused on climate perceptions and climate projections, limited to changes in precipitation and temperature, through the hazard-activity pair's methodology. In general, the complex process of touristic decisions is also influenced by intertwined personal factors such as finances, timing, security alongside expectations and personal perceptions (Mudarra-Fernández et al. 2019; Rutty and Scott 2015), which influence the behavior and satisfaction and travel motivations of tourists. Unpacking these factors in the South African context is valuable for future research focuses.

\section{c. Outlook and conclusions}

On a global scale, climate change is argued to have a negative influence on the future development of tourism.
Climate change impacts on tourism in Africa are expected to be severe (Scott et al. 2015). This is concerning as the African continent (among others) has a particularly high vulnerability to climate change, and tourism contributes a large proportion of the GDP and expects strong growth in forthcoming decades (Scott et al. 2019). Our study found that both climate change-induced temperature rise and precipitation change are projected to have an influence on beach tourism in South Africa. These impacts might seem rather positive for short-term tourism development in South Africa. Although we have not addressed these changes in this study, considering the potential impacts of increasing extreme events and progressive SLR on beach destinations, both on a global scale (Jenkins 2018; Scott and Verkoeyen 2018; Toubes et al. 2017) and for South Africa (Fitchett et al. 2016a; Hoogendoorn et al. 2016; Palmer et al. 2011), future tourism in the country will most likely suffer because of climate change impacts (Scott et al. 2015). Climate change will reduce the net climatic suitability of destinations for tourism, with reductions in sunshine and increases in wind and humidity (Hall 2018; Scott et al. 2015). This includes indirectly and induced impacts tourism destinations may face through effects on other sectors such as agrarian production of commodities.

However, this research shows that the hazard-activity methodology is applicable for the specific context of South Africa and beach tourism in terms of influence of temperature and precipitation change of the recreational activity of beach tourism: relaxing and particularly sunbathing at the beach. This is of concern as the data basis in terms of downscaled climate models for the global south-and therefore South Africa-is lacking relative to the global north. It also demonstrates that the global concepts of vulnerability and the associated methodologies are partly transferable to the global south and the specific context of South Africa, and, vice versa, insights from (southern) African case studies can possibly be adapted on a global scale.

However, the analyses of two hazard-activity pairs (precipitation, temperature, and beach tourism) are only one piece of a vulnerability assessment (cf. Moreno and Becken 2009) and therefore cannot stand alone when talking about future impacts of climate change on 
beach tourism destinations. To comprehensively determine potential threats of climate change to beach tourism, further hazard-activity pairs (which have been omitted in this study) are needed that focus on climate change-induced changes of humidity, sunshine, and wind; the interplay and entanglement of these factors toward the creation of climatic comfort of tourists; and effects such as SLR and indirect effects such as water scarcity or policy change in relation to other activities that make up a beach holiday. To fulfil a comprehensive vulnerability assessment of beach tourism destinations, hazard-activity pairs alongside tourism stakeholder perceptions and analyses of the region's adaptive capacity, including a comprehensive data collection, are required.

The research in this paper sheds light on the complex threats climate change poses to various economic sectors with a focus on beach tourism in South Africa. Against this backdrop, this study will ideally support governments, tourism stakeholders, and the broader society of the global south in adapting to potential future climate change impacts through the provision of information on potential threats. This allows the economic contribution of tourism in South Africa to be sustained, which is critical in a country suffering from high unemployment levels. Among others, this study also shows the urgency of a global social-ecological transformation to mitigate potential climate change impacts and to create a sustainable tourism sector as we have shown that there are differences in climate change impacts projected through RCP4.5 and RCP8.5.

Acknowledgments. The authors are grateful to the editor and the three anonymous reviewers whose comments and suggestions significantly improved both clarity and precision of the paper. In addition, the authors want to thank CIP (2019) for offering free downscaled climate data for the whole African continent. This study was supported financially by the Erasmus Mundus Inspire Programme for authors Friedrich and Stahl.

\section{REFERENCES}

Adesina, A. J., K. R. Kumar, and V. Sivakumar, 2016: Aerosolcloud-precipitation interactions over major cities in South Africa: Impact on regional environment and climate change. Aerosol Air Qual. Res., 16, 195-211, https://doi.org/10.4209/ aaqr.2015.03.0185.

Agard, J., and E. L. F. Schipper, Eds., 2014: Glossary. Climate Change 2014: Impacts, Adaptation and Vulnerability. Part B. Regional Aspects, Cambridge University Press, 1757-1776.

Calgaro, E., K. Lloyd, and D. Dominey-Howes, 2014: From vulnerability to transformation: A framework for assessing the vulnerability and resilience of tourism destinations. J. Sustainable Tourism, 22, 341-360, https://doi.org/10.1080/ 09669582.2013.826229.
CIP, 2019: African merged stations CMIP5. Climate Information Platform, accessed 23 April 2019, http://cip.csag.uct.ac.za/ webclient2/datasets/africa-merged-cmip5/.

Denstadli, J. M., J. K. S. Jacobsen, and M. Lohmann, 2011: Tourist perceptions of summer weather in Scandinavia. Ann. Tourism Res., 38, 920-940, https://doi.org/10.1016/j.annals.2011.01.005.

Department of Environmental Affairs, 2013: Climate trends and scenarios for South Africa. Long-Term Adaptation Scenarios, Flagship Research Programme Rep., 2-5, https:/www.environment.gov.za/sites/default/files/docs/ summary_policymakers_bookV3.pdf.

Dube, K., and G. Nhamo, 2018: Climate variability, change and potential impacts on tourism: Evidence from the Zambian side of the Victoria Falls. Environ. Sci. Policy, 84, 113-123, https:// doi.org/10.1016/j.envsci.2018.03.009.

$\longrightarrow$, and - 2019: Climate change and potential impacts on tourism: Evidence from the Zimbabwean side of the Victoria Falls. Environ. Dev. Sustainability, 21, 2025-2041, https:// doi.org/10.1007/S10668-018-0118-Y.

$\longrightarrow$, and - 2020: Evidence and impact of climate change on South African national parks. Potential implications for tourism in the Kruger National Park. Environ. Dev., 33, 100485, https://doi.org/10.1016/J.ENVDEV.2019.100485.

Dyson, L. L., 2009: Heavy daily-rainfall characteristics over the Gauteng Province. Water SA, 35, 627-638, https://doi.org/ 10.4314/wsa.v35i5.49188.

Fitchett, J. M., 2019: The Holocene climates of South Africa. The Geography of South Africa, J. Knight and C. M. Rogerson, Eds., Springer International Publishing, 47-56.

- , and G. Hoogendoorn, 2018: An analysis of factors affecting tourists' accounts of weather in South Africa. Int. J. Biometeor., 62, 2161-2172, https://doi.org/10.1007/s00484018-1617-0.

— and - 2019: Exploring the climate sensitivity of tourists to South Africa through TripAdvisor reviews. S. Afr. Geogr. J., 101, 91-109, https://doi.org/10.1080/03736245.2018.1541022.

_ , B. Grant, and G. Hoogendoorn, 2016a: Climate change threats to two low-lying South African coastal towns: Risks and perceptions. S. Afr. J. Sci., 112 (5/6), 1-9, https://doi.org/ 10.17159/sajs.2016/20150262.

— G. Hoogendoorn, and A. M. Swemmer, 2016b: Economic costs of the 2012 floods on tourism in the Mopani district municipality, South Africa. Trans. Roy. Soc. S. Afr., 71, 187194, https://doi.org/10.1080/0035919X.2016.1167788.

, D. Robinson, and G. Hoogendoorn, 2017: Climate suitability for tourism in South Africa. J. Sustainable Tourism, 25, 851867, https://doi.org/10.1080/09669582.2016.1251933.

Friedrich, J., J. Stahl, G. Hoogendoorn, and J. M. Fitchett, 2020: To beach or not to beach? Socio-economic factors influencing beach tourists' perceptions of climate and weather in South Africa. Trans. Roy. Soc. S. Afr., https://doi.org/ 10.1080/0035919X.2020.1716869, in press.

Füssel, H.-M., 2007: Vulnerability: A generally applicable conceptual framework for climate change research. Global Environ. Change, 17, 155-167, https://doi.org/10.1016/j.gloenvcha.2006.05.002.

Georgopoulou, E., S. Mirasgedis, Y. Sarafidis, V. Hontou, N. Gakis, and D. P. Lalas, 2019: Climatic preferences for beach tourism: An empirical study on Greek islands. Theor. Appl. Climatol., 137, 667-691, https://doi.org/10.1007/S00704-018-2612-4.

Giddy, J. K., J. M. Fitchett, and G. Hoogendoorn, 2017: Insight into American tourists' experiences with weather in South Africa. Bull. Geogr. Socio-Econ. Ser., 38, 57-72, https://doi.org/ 10.1515/BOG-2017-0034. 
Gómez-Martín, M. B., and E. Martínez-Ibarra, 2012: Tourism demand and atmospheric parameters: Non-intrusive observation techniques. Climate Res., 51, 135-145, https://doi.org/10.3354/ cr01068.

Gössling, S., M. Bredberg, A. Randow, E. Sandström, and P. Svensson, 2006: Tourist perceptions of climate change: A study of International tourists in Zanzibar. Curr. Issues Tourism, 9, 419-435, https://doi.org/10.2167/cit265.0.

Hall, C. M., 2018: Climate change and its impacts on coastal tourism: Regional assessments, gaps and issues. Global Climate Change and Coastal Tourism: Recognizing Problems, Managing Solutions and Future Expectations, A. L. Jones and M. R. Phillips, Eds., CABI, 48-61.

Hambira, W. L., J. Saarinen, H. Manwa, and J. R. Atlhopheng, 2013: Climate change adaptation practices in nature-based tourism in Maun in the Okavango Delta area, Botswana: How prepared are the tourism businesses? Tourism Rev. Int., 17, 19-29, https://doi.org/10.3727/154427213X13649094288025.

Hoogendoorn, G., and J. M. Fitchett, 2018a: Climate change and tourism research in South Africa: Prospects and obstacles for mixed-method approaches. Handbook of Research Methods for Tourism and Hospitality Management, R. Nunkoo, Ed., Edward Elgar Publishing, 441-449.

$\longrightarrow$, and $\_, 2018 \mathrm{~b}$ : Tourism and climate change: A review of threats and adaptation strategies for Africa. Curr. Issues Tourism, 21, 742-759, https://doi.org/10.1080/13683500.2016.1188893.

_ and 2020: Fourteen years of tourism and climate change research in southern Africa: Lessons on sustainability under conditions of global change. Natural Resources, Tourism and Community Livelihoods in Southern Africa: Challenges of Sustainable Development, M. Stone, M. Lenao, and N. Moswete, Eds., Routledge, 78-89.

, B. Grant, and J. M. Fitchett, 2016: Disjunct perceptions? Climate change threats in two-low lying South African coastal towns. Bull. Geogr. Socio-Econom. Ser., 31, 59-71, https:// doi.org/10.1515/BOG-2016-0005.

Hübner, A., and S. Gössling, 2012: Tourist perceptions of extreme weather events in Martinique. J. Destination Mark. Manage., 1, 47-55, https://doi.org/10.1016/j.jdmm.2012.09.003.

James, R., and Coauthors, 2018: Evaluating climate models with an African lens. Bull. Amer. Meteor. Soc., 99, 313-336, https:// doi.org/10.1175/BAMS-D-16-0090.1.

Jenkins, I., 2018: Climate change and tourism sustainability. Global Climate Change and Coastal Tourism: Recognizing Problems, Managing Solutions and Future Expectations, A. L. Jones and M. R. Phillips, Eds., CABI, 34-47.

Jury, M. R., 2019: South Africa's future climate: Trends and projections. The Geography of South Africa, J. Knight and C. M. Rogerson, Eds., Springer International Publishing, 305-312.

Kaján, E., and J. Saarinen, 2013: Tourism, climate change and adaptation: A review. Curr. Issues Tourism, 16, 167-195, https://doi.org/10.1080/13683500.2013.774323.

Kilungu, H., R. Leemans, P. K. T. Munishi, S. Nicholls, and B. Amelung, 2017: Climate change threatens major tourist attractions and tourism in Serengeti National Park, Tanzania. Climate Change Adaptation in Africa: Fostering Resilience and Capacity to Adapt, W. L. Filho et al., Eds., Springer International Publishing, 375-392.

,,,--- and -2019 : Forty years of climate and land-cover change and its effects on tourism resources in Kilimanjaro National Park. Tourism Plann. Dev., 16, 235-253, https://doi.org/10.1080/21568316.2019.1569121.
Kruger, A. C., and M. P. Nxumalo, 2017: Surface temperature trends from homogenized time series in South Africa: 19312015. Int. J. Climatol., 37, 2364-2377, https://doi.org/10.1002/ joc. 4851.

Kurniawan, F., L. Adrianto, D. G. Bengen, and L. B. Prasetyo, 2016: Vulnerability assessment of small islands to tourism: The case of the Marine Tourism Park of the Gili Matra Islands, Indonesia. Global Ecol. Conserv., 6, 308-326, https://doi.org/ 10.1016/j.gecco.2016.04.001.

Lam, C. K. C., M. Loughnan, and N. Tapper, 2018: Visitors' perception of thermal comfort during extreme heat events at the Royal Botanic Garden Melbourne. Int. J. Biometeor., 62, 97 112, https://doi.org/10.1007/s00484-015-1125-4.

Lennard, C., 2019: Multi-scale drivers of the South African weather and climate. The Geography of South Africa, J. Knight and C. M. Rogerson, Eds., Springer International Publishing, 81-89.

Lew, A. A., 2010: Time as a major barrier to sustainable development. Tourism Geogr., 12, 481-483, https://doi.org/10.1080/ 14616688.2010 .494924$.

MacKellar, N., M. New, and C. Jack, 2014: Observed and modelled trends in rainfall and temperature for South Africa: 19602010. S. Afr. J. Sci., 110 (7/8), 1-13, https://doi.org/10.1590/ sajs.2014/20130353.

Mather, A. A., and D. Stretch, 2012: A perspective on sea level rise and coastal storm surge from southern and eastern Africa: A case study near Durban, South Africa. Water, 4, 237-259, https://doi.org/10.3390/w4010237.

Mathetsa, S. M., M. D. Simatele, I. T. Rampedi, and G. Gericke, 2019: Perspectives on integrated water resource management and its relevance in understanding the water-energy-climate change nexus in South Africa. J. Energy S. Afr., 30, 11-21, https://doi.org/10.17159/2413-3051/2019/v30i3a5654.

Moreno, A., 2010: Mediterranean tourism and climate (change): A survey-based study. Tourism Hospitality Plann. Dev., 7, 253 265, https://doi.org/10.1080/1479053X.2010.502384.

_ - and S. Becken, 2009: A climate change vulnerability assessment methodology for coastal tourism. J. Sustainable Tourism, 17, 473-488, https://doi.org/10.1080/09669580802651681.

Mudarra-Fernández, A. B., I. Carrillo-Hidalgo, and J. I. PulidoFernández, 2019: Factors influencing tourist expenditure by tourism typologies: A systematic review. Anatolia, 30, 18-34, https://doi.org/10.1080/13032917.2018.1495086.

Musekiwa, C., H. C. Cawthra, M. Unterner, and F. W. van Zyl, 2015: An assessment of coastal vulnerability for the South African coast. S. Afr. J. Geomatics, 4, 123-137, https://doi.org/ 10.4314/sajg.v4i2.5.

Mushawemhuka, W., J. M. Rogerson, and J. Saarinen, 2018: Nature-based tourism operators' perceptions and adaptation to climate change in Hwange National Park, Zimbabwe. Bull. Geogr. Socio-Econ. Ser., 42, 115-127, https://doi.org/ 10.2478/BOG-2018-0034.

NASA, 2019: U.S. releases enhanced shuttle land elevation data. Jet Propulsion Laboratory, https://www2.jpl.nasa.gov/srtm/.

National Centers for Environmental Information, 2019: Climate data online. Accessed 13 February 2019, https://www.ncdc.noaa.gov/ cdo-web/.

O'Brien, K., and Coauthors, 2004: Mapping vulnerability to multiple stressors: Climate change and globalization in India Global Environ. Change, 14, 303-313, https://doi.org/10.1016/ j.gloenvcha.2004.01.001.

Orimoloye, I. R., O. O. Ololade, S. P. Mazinyo, A. M. Kalumba, O. Y. Ekundayo, E. T. Busayo, A. A. Akinsanola, and W. Nel, 2019: Spatial assessment of drought severity in Cape Town 
area, South Africa. Heliyon, 5, e02148, https://doi.org/10.1016/ j.heliyon.2019.e02148.

Palmer, B. J., and Coauthors, 2011: Preliminary coastal vulnerability assessment for KwaZulu-Natal, South Africa. J. Coastal Res., 1390-1395.

Pandy, W. R., 2017: Tourism enterprises and climate change: Some research imperatives. Afr. J. Hospitality Tourism Leisure, 6, 18. , and C. M. Rogerson, 2018: Tourism and climate change: Stakeholder perceptions of at risk tourism segments in South Africa. Euro Economica, 37, 104-118.

Peel, M. C., B. L. Finlayson, and T. A. McMahon, 2007: Updated world map of the Köppen-Geiger climate classification. Hydrol. Earth Syst. Sci., 11, 1633-1644, https://doi.org/10.5194/ hess-11-1633-2007.

Perkins, D. P., and K. G. Debbage, 2016: Weather and tourism: Thermal comfort and zoological park visitor attendance. Atmosphere, 7, 44, https://doi.org/10.3390/atmos7030044.

Pintassilgo, P., J. Rosselló, M. Santana-Gallego, and E. Valle, 2016: The economic dimension of climate change impacts on tourism: The case of Portugal. Tourism Econ., 22, 685-698, https:// doi.org/10.1177/1354816616654242.

Polsky, C., R. Neff, and B. Yarnal, 2007: Building comparable global change vulnerability assessments: The vulnerability scoping diagram. Global Environ. Change, 17, 472-485, https://doi.org/10.1016/j.gloenvcha.2007.01.005.

Potchter, O., P. Cohen, T.-P. Lin, and A. Matzarakis, 2018: Outdoor human thermal perception in various climates: A comprehensive review of approaches, methods and quantification. Sci. Total Environ., 631-632, 390-406, https://doi.org/ 10.1016/j.scitotenv.2018.02.276.

Preston-Whyte, R. A., and H. K. Watson, 2005: Nature tourism and climatic change in southern Africa. Tourism, Recreation and Climate Change, C. M. Hall and J. Higham, Eds., Channel View Publications, 130-142.

Roffe, S. J., J. M. Fitchett, and C. J. Curtis, 2019: Classifying and mapping rainfall seasonality in South Africa: A review. S. Afr. Geogr. J., 101, 158-174, https://doi.org/10.1080/03736245.2019.1573151.

Rogerson, C. M., 2016: Climate change, tourism and local economic development in South Africa. J. Local Economy Policy Unit, 31, 322-331, https://doi.org/10.1177/0269094215624354.

— 2017: Less visited tourism spaces in South Africa. Afr. J. Hospitality Tourism Leisure, 6, 1-17.

Rutty, M., and D. Scott, 2010: Will the Mediterranean become "too hot" for tourism? A reassessment. Tourism Hospitality Plann. Dev., 7, 267-281, https://doi.org/10.1080/1479053X.2010.502386.

— tional beach tourists. Climate Res., 57, 259-269, https://doi.org/ 10.3354/cr01183.

— and _ 2014: Thermal range of coastal tourism resort microclimates. Tourism Geogr., 16, 346-363, https://doi.org/ 10.1080/14616688.2014.932833.

—_, and ——, 2015: Bioclimatic comfort and the thermal perceptions and preferences of beach tourists. Int. J. Biometeor., 59, 37-45, https://doi.org/10.1007/s00484014-0820-x.

— mestic and international beach holidays: A case study of Canadian travelers. Atmosphere, 7, 30, https://doi.org/10.3390/ atmos 7020030 .

Santos-Lacueva, R., S. A. Clavé, and Ò. Saladié, 2017: The vulnerability of coastal tourism destinations to climate change: The usefulness of policy analysis. Sustainability, 9, 2062, https://doi.org/10.3390/su9112062.
Scott, D., and C. Lemieux, 2010: Weather and climate information for tourism. Procedia Environ. Sci., 1, 146-183, https://doi.org/ 10.1016/j.proenv.2010.09.011.

— , and S. Gössling, 2015: What could the next 40 years hold for global tourism? Tourism Recreation Res., 40, 269-285, https:// doi.org/10.1080/02508281.2015.1075739.

— coastal-island destination. Global Climate Change and Coastal Tourism: Recognizing Problems, Managing Solutions and Future Expectations, A. L. Jones and M. R. Phillips, Eds., CABI, 62-73.

_ S. Gössling, and C. R. de Freitas, 2008: Preferred climates for tourism: Case studies from Canada, New Zealand and Sweden. Climate Res., 45, 61-73, https://doi.org/10.3354/cr00774.

_ C. M. Hall, and S. Gössling, 2015: A review of the IPCC Fifth Assessment and implications for tourism sector climate resilience and decarbonization. J. Sustainable Tourism, 29 (1), 1-23, https://doi.org/10.1080/09669582.2015.1062021.

,-- , and $-2016 \mathrm{a}$ : A report on the Paris climate change agreement and its implications for tourism: Why we will always have Paris. J. Sustainable Tourism, 24, 933-948, https:// doi.org/10.1080/09669582.2016.1187623.

—, M. Rutty, B. Amelung, and M. Tang, 2016b: An intercomparison of the holiday climate index (HCI) and the tourism climate index (TCI) in Europe. Atmosphere, 7, 80, https:// doi.org/10.3390/atmos7060080.

_ C. M. Hall, and S. Gössling, 2019: Global tourism vulnerability to climate change. Ann. Tourism Res., 77, 49-61, https:// doi.org/10.1016/j.annals.2019.05.007.

Sousa, P. M., R. C. Blamey, C. J. C. Reason, A. M. Ramos, and R. M. Trigo, 2018: The 'Day Zero' Cape Town drought and the poleward migration of moisture corridors. Environ. Res. Lett., 13, 124025, https://doi.org/10.1088/1748-9326/aaebc7.

South African National Biodiversity Institute, 2019: The status of South Africa's ecosystems and biodiversity. National Biodiversity Assessment 2018: Facts, Findings \& Messages, SANBI Doc., 9 pp., http://hdl.handle.net/20.500.12143/6639.

South African Weather Service, 2017: A climate change reference atlas. SAWS Doc., 39 pp., https://www.weathersa.co.za/Documents/ Climate/SAWS_CC_REFERENCE_ATLAS_PAGES.pdf.

Statistics South Africa, 2017: Domestic tourism survey 2017: January to December 2017. Stats SA Rep., 123 pp., http:// www.statssa.gov.za/publications/P03521/P035212017.pdf.

Steiger, R., 2010: The impact of climate change on ski season length and snowmaking requirements in Tyrol, Austria. Climate Res., 43, 251-262, https://doi.org/10.3354/cr00941.

—, D. Scott, B. Abegg, M. Pons, and C. Aall, 2019: A critical review of climate change risk for ski tourism. Curr. Issues Tourism, 22, 1343-1379, https://doi.org/10.1080/13683500.2017.1410110.

Taylor, K. E., R. J. Stouffer, and G. A. Meehl, 2012: An overview of CMIP5 and the experiment design. Bull. Amer. Meteor. Soc., 93, 485-498, https://doi.org/10.1175/BAMSD-11-00094.1.

Tervo-Kankare, K., J. Saarinen, M. E. Kimaro, and N. N. Moswete, 2018a: Nature-based tourism operators' responses to changing environment and climate in Uis, Namibia. Afr. Geogr. Rev., 37, 273-282, https://doi.org/10.1080/19376812.2017.1286246.

, E. Kaján, and J. Saarinen, 2018b: Costs and benefits of environmental change: Tourism industry's responses in Arctic Finland. Tourism Geogr., 20, 202-223, https://doi.org/10.1080/ 14616688.2017.1375973.

Toubes, D., S. Gössling, C. Hall, and D. Scott, 2017: Vulnerability of coastal beach tourism to flooding: A case study of Galicia, Spain. Environments, 4, 83, https://doi.org/10.3390/environments4040083. 
Truong, V. D., and A. Le, 2018: Case study Vietnam: Climate change vulnerability assessment of coastal tourism in $\mathrm{Cu}$ Lao Cham Island. Global Climate Change and Coastal Tourism: Recognizing Problems, Managing Solutions and Future Expectations, A. L. Jones and M. R. Phillips, Eds., CABI, 221-230.

Turner, M. D., 2016: Climate vulnerability as a relational concept. Geoforum, 68,29-38, https://doi.org/10.1016/j.geoforum. 2015.11.006.

UNWTO, 2018: UNWTO tourism highlights: 2018 edition. World Tourism Organization, 20 pp., https://www.e-unwto.org/doi/ pdf/10.18111/9789284419876.

2020: World Tourism Barometer and Statistical Annex. No. 18, World Tourism Organization Doc., 48 pp., https://doi.org/ 10.18111/wtobarometereng. van Vuuren, D. P., and Coauthors, 2011: The representative concentration pathways: An overview. Climatic Change, 109, 5-31, https://doi.org/10.1007/s10584-011-0148-z.

World Travel and Tourism Council, 2020: South Africa-2020 Annual research: Key highlights. WTTC Doc., 1 p., https:// wttc.org/Research/Economic-Impact/moduleId/704/itemId/204/ controller/DownloadRequest/action/QuickDownload.

Ziervogel, G., 2019: Unpacking the Cape Town drought: Lessons learned. Cities Support Programme Rep., 26 pp., https:// www.africancentreforcities.net/wp-content/uploads/2019/02/ Ziervogel-2019-Lessons-from-Cape-Town-Drought_A.pdf. , and Coauthors, 2014: Climate change impacts and adaptation in South Africa. Wiley Interdiscip. Rev.: Climate Change, 5, 605-620, https://doi.org/10.1002/wcc.295. 